\title{
THE STAINING OF PROTEINS AND LIPOIDS ELECTROPHORESIS ON FILTER PAPER
}

\author{
W. LOEFFLER AND C. WUNDERLY \\ From the Medical University Clinic, Zürich
}

(RECEIVED FOR PUBLICATION MARCH 7. 1953)

The advantages of micro-electrophoresis of proteins on filter paper are manifold and have led to a widespread use of this inexpensive and efficient routine method. Flynn and de Mayo (1951) have given a good description of the method. Our experience has led us to the conclusion that this method is particularly useful for examining the proteins in various body fluids, such as the cerebrospinal fluid, oedema fluid, ascitic fluid, and aqueous fluids (Wunderly and Cagianut, 1952). As only 1.5 or $2 \mathrm{mg}$. of protein is required for the qualitative technique, even normal cerebrospinal fluid can be successfully analysed (Wallenius, 1952: Caspani, 1952). The various protein fractions are completeiy separated according to their different mobilities in a given electrical field and according to their $p \mathrm{H}$. The separation is then made visible by staining the proteins histochemically in the paper strip. Experience has proved that not only do the various subfractions of normal serum proteins show a different uptake of the stain, but that deviations are even larger when sera from pathological cases are studied (Köiw, Wallenius, and Grönwall, 1952). In order to secure the required accuracy it was necessary to find a stain whose uptake by various proteins was as constant as possible. We therefore compared the three stains most widely used in paper electrophoresis, bromphenol blue, amidoblack, and azocarmine, for their uptake by isolated serum protein fractions.

In disease the concentration of serum lipids often undergoes the biggest deviation of all the serum components, and their characterization makes it possible to furnish new data for diagnosis and prognosis. A simple technique for staining serum lipids is also described.

\section{Method of Staining Serum Protein Fractions on Filter Paper}

The isolated serum protein fractions were obtained by making preliminary use of electrophoresis on thick filter paper, whereby $1 \mathrm{ml}$. of serum is fractionated at $2^{\circ} \mathrm{C}$. within 24 hours (Wunderly, 1952). The frac- tions are then dialysed against distilled water in order to get rid of buffer substances. Dialysis is continued against $10 \%$ dextran solution, which has a concentrating effect. Samples are then measured in the Beckman spectrophotometer at wavelength $280 \mathrm{~m} \mu \stackrel{\infty}{\mathrm{N}}$ and brought to a concentration of $200 \mathrm{mg} . \%^{\prime}$ Of 을 these solutions. $0.05 \mathrm{ml}$. was placed on strips of Munktell filter paper No. 20/150 (Grycksbo, $\bar{Z}$ Sweden), which had previously been washed with "propanol." The dried paper strips were stained as follows:

Azocarmine B (Plückthun and Götting, 1951).--The $\stackrel{\mathbb{C}}{-}$ paper strips remain for 10 minutes in a solution of $\vec{\theta}$ $0.75^{\circ}$, azocarmine $\mathbf{B}+10^{\circ}$ glacial acetic acid and o $50 \%$ methanol; they are then washed in methanol $10 \%$ glacial acetic acid for five minutes and $10 \%$ glacial acetic acid for another five minutes.

Amidoblack 10 B (same as naphthalene black $12 \stackrel{\text { B }}{\circ}$ 200. I.C.I.) (Grassmann and Hannig, 1950, 1952).- ఊ The paper strips remain for 10 minutes in a mixture $\mathbb{Q}$ of 9 parts of methyl alcohol and 1 part glacial acetic $\overrightarrow{\vec{P}}$ acid which is saturated with amidoblack $10 \mathrm{~B}$. After- 을 wards the paper strips are washed for about four hours with the same solution, but without the dye. The solution is renewed until the paper is only light blue.

Bromphenol Blue (Kunkel and Tiselius, 1951).--The paper strips remain for eight minutes in an ethyl 3 . alcohol solution containing $1 \%$ bromphenol blue and are saturated with $\mathrm{HgCl}_{2}$. For washing the stain $\frac{\mathrm{O}}{3}$ from the paper, $0.5_{\%}^{\circ}$ acetic acid in $50 \%$ methanol and in $50 \%$ ethanol were used alternatively. After four such washings the paper appears a bluish white $D$ again and is dried at room temperature.

The stained spots (Fig. 1) were cut out and eluted N with $50 \%$ methyl alcohol containing $4 \%$ sodium carbonate. Optical densities of equal volumes were read in the Beckman spectrophotometer on wavelength ${ }_{\omega}^{N}$ $570 \mathrm{~m} \mu$ for azocarmine and on $595 \mathrm{~m} \mu$ for amidoblacko and bromphenol blue. Blanks were obtained by cutting out discs of paper of the same size as the stained spots of protein and eluting them accordingly. Determinations of the blanks are necessary because even an intense washing leaves the paper treated with amido- $\frac{0}{0}$ black slightly blue and that with bromphenol blue $\mathrm{a} \stackrel{\mathrm{C}}{\mathrm{O}}$ bluish white : only azocarmine is washed out quantita-o 
tively (see Fig. 1) and leaves the background to the protein stains a pure white.

Cremer and Tiselius (1950) were the first who compared the quantitative results of the classical Tiselius method with those obtained by paper electrophoresis. They found that it was necessary to multiply the g'obulin values obtained by paper

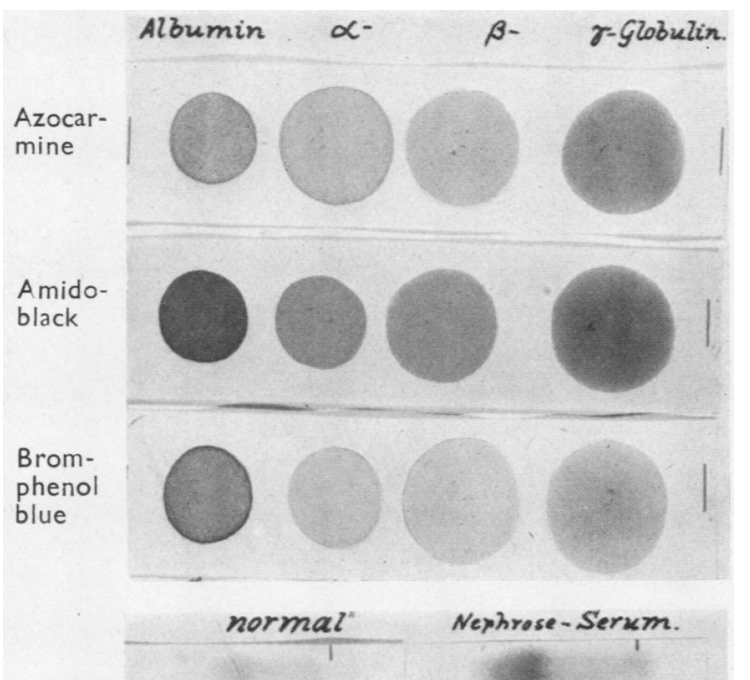

Ciba

blue-

Sudan

black

Sudan

red

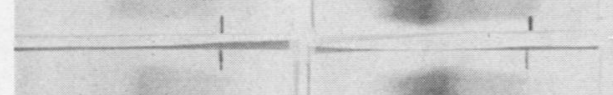

.

\begin{tabular}{|c|c|c|c|c|c|c|}
\hline \multirow{2}{*}{ Author } & \multirow{2}{*}{ Stain } & \multirow{2}{*}{\multicolumn{5}{|c|}{$\begin{array}{l}\text { Globulin Correction Factors } \\
\end{array}$}} \\
\hline & & $a_{1}$ & & & & \\
\hline 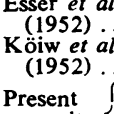 & 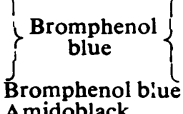 & $\begin{array}{l}2.36 \\
2.8\end{array}$ & & $\begin{array}{l}2.09 \\
1.7\end{array}$ & $\begin{array}{l}2,20 \\
1.64 \\
1.84\end{array}$ & 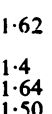 \\
\hline & & & $\begin{array}{l}1 \cdot 18 \\
0\end{array}$ & & & \\
\hline
\end{tabular}

fore adequate reproducibility is best assured by using azocarmine.

Compared with the changes in serum protein composition during disease the changes in the lipoid composition are even more pronounced. In order to characterize them Swahn (1952), Wunderly and Pezold (1952), and Kunkel and Slater (1952) adopted almost simultaneously modern paper methods. The procedure which we describe here is intended for routine purposes and can be executed in any apparatus fit for paper electrophoresis.

\section{Method for Staining Lipoids on Filter Paper}

For the sake of comparison we place on one strip of Munktell paper No. 150/20 $0.015 \mathrm{ml}$. of serum for protein staining (a), and on another strip $0.12 \mathrm{ml}$. for lipoid staining (b) ; both paper strips are run in the same apparatus to make sure of strictly comparable mobilities of protein fractions. After electrophoresis. strip (a) is stained by one of the methods described above. For the staining of strip (b) a solution of $40 \mathrm{mg}$. "ciba," blue and $40 \mathrm{mg}$. Sudan black in $120 \mathrm{ml}$. $96 \%$ alcohol is warmed to $65^{\circ} \mathrm{C}$. and poured slowly under slight agitation into $10 \mathrm{ml}$. of $4 \%$ sodium carbonate, which has similarly been warmed to $65^{\circ} \mathrm{C}$. The filtrate of these solutions, while still warm, is used for staining. The paper strips remain in it for nine minutes, then they are placed in a bath of $40 \%$ alcohol and $5 \%$ glacial acetic acid. After an hour all the superfluous fat dyes have been removed and the paper strips are dried in air. Fig. 1 shows the results of such staining with a normal serum and a nephrotic serum. Below this there are the results of the same sera stained with a mixture of phenol-acetic acid-Sudan III as described by Jackson (cf. Glick, 1949). Both methods give comparable results, but if the stains are eluted in order to gain a curve, the "ciba" blue-Sudan black stain gives higher optical densities. The curves of the lipoid stains in Figs. 2 and 3 were obtained by this method. To achieve this the coloured paper strips are cut in small strips of $5 \mathrm{~mm}$. breadth; each of these strips is eluted in $5 \mathrm{ml}$. of $96 \%$ alcohol and $5 \%$ glacial acetic acid. The elution is complete after two hours and the optical density of the solution can be read in the Beckman spectrophotometer at the wavelength of $595 \mathrm{~m} \mu$. Each reading provides a point of the lipoid- 
TABLE 11

\begin{tabular}{|c|c|c|c|c|c|c|c|c|c|c|c|}
\hline \multirow[b]{2}{*}{$\begin{array}{c}\text { Composition of Sera } \\
\text { on Fig. } 2\end{array}$} & \multirow{2}{*}{$\begin{array}{c}\text { Total } \\
\text { Protein } \\
(\mathrm{g} . \%)\end{array}$} & \multicolumn{5}{|c|}{ Serum Proteins } & \multicolumn{3}{|c|}{ Cholesterol } & \multirow[b]{2}{*}{$\begin{array}{c}\text { Neutral } \\
\text { Fats } \\
(\mathrm{mg} \%)\end{array}$} & \multirow{2}{*}{$\begin{array}{l}\text { Phosph } \\
\text { lipids } \\
\text { (mg.\% }\end{array}$} \\
\hline & & Alb. & $a_{1}$ & $\alpha_{2}$ & $\beta$ & $\gamma$ & $\begin{array}{l}\text { Total } \\
(\mathrm{mg} \% \%)\end{array}$ & $\begin{array}{c}\text { Free } \\
(\mathrm{mg} \%)\end{array}$ & $\begin{array}{c}\text { Ester } \\
\text { Quota } \\
(\%)\end{array}$ & & \\
\hline W.E. Lipoid nephrosis & $2 \cdot 95$ & $14 \cdot 6$ & $1 \cdot 9$ & $65 \cdot 5$ & $14 \cdot 6$ & $3 \cdot 4$ & 810 & 230 & 72 & 130 & 355 \\
\hline M.R. , , , & $3 \cdot 10$ & 10.9 & $3 \cdot 9$ & $67 \cdot 0$ & $11 \cdot 2$ & $7 \cdot 0$ & 590 & 236 & 60 & 404 & 281 \\
\hline A.O. $\gamma$-myeloma & $7 \cdot 72$ & 48.9 & $5 \cdot 6$ & $8 \cdot 8$ & $11 \cdot 2$ & $25 \cdot 5$ & 130 & 48 & 63 & 325 & 255 \\
\hline
\end{tabular}

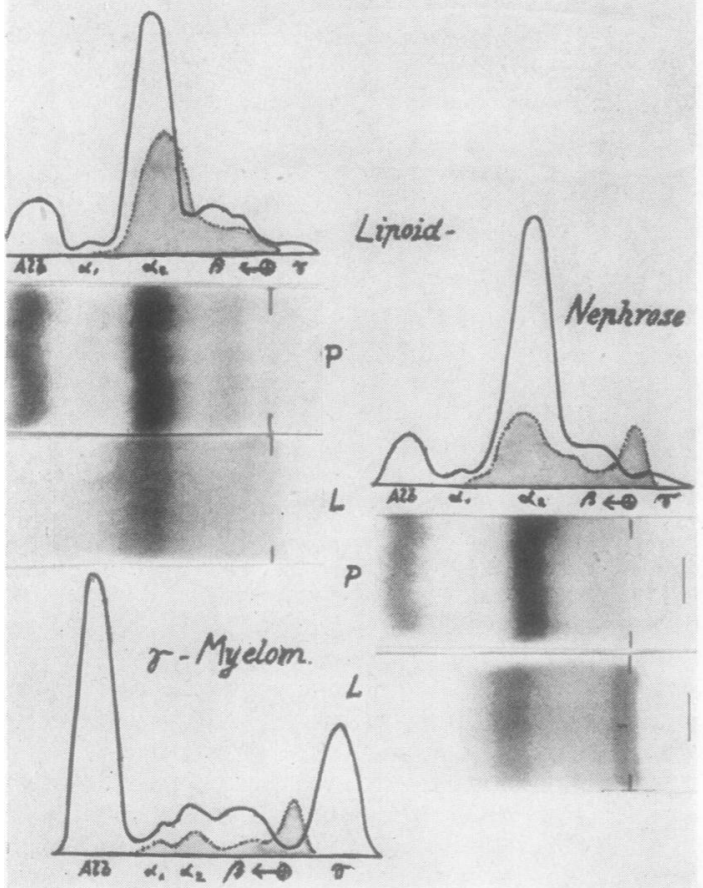

FIG. 2

FIG. 2.-Diagrams of protein and lipoid composition of two nephrosis sera and a myeloma serum.
Differenzierung von Protein und Linoid.

Uroprotein

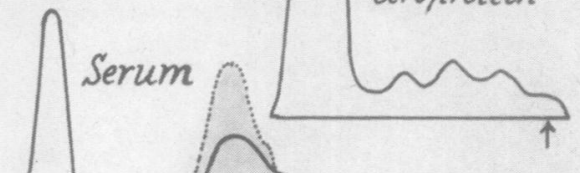

Okt.1952
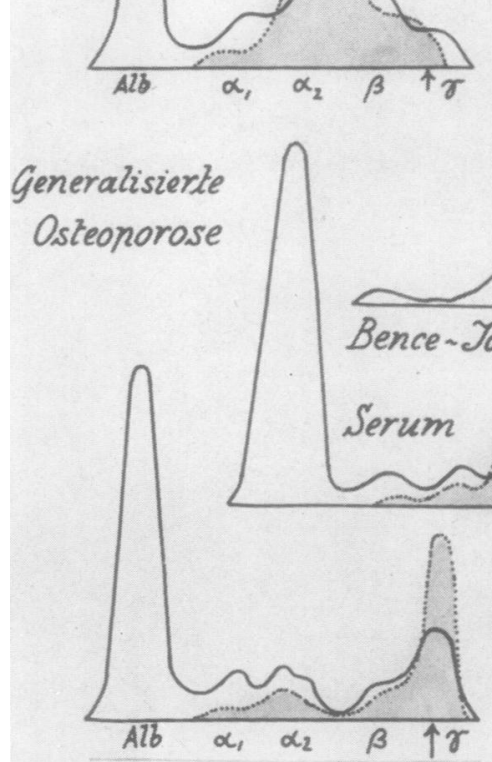

Henato-

snleno.

megalie

Linoia in

Serum and uroprotein of a patient with toxaemia of pregnancy, a patient with generalized osteoporosis, and the serum of a case of hepato-splenomegalic disease.

Fig. 3

TABLE III

\begin{tabular}{|c|c|c|c|c|c|c|c|c|}
\hline \multirow{2}{*}{$\begin{array}{l}\text { Total } \\
\text { Protein } \\
(\mathbf{g} \% \%)\end{array}$} & \multicolumn{5}{|c|}{ Serum Proteins } & \multicolumn{3}{|c|}{ Cholesterol } \\
\hline & Alb. & $a_{1}$ & $a_{2}$ & $\beta$ & $\gamma$ & $\begin{array}{c}\text { Total } \\
\text { (mg.\%) }\end{array}$ & $\begin{array}{c}\text { Free } \\
(\mathrm{mg} \%)\end{array}$ & 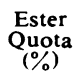 \\
\hline $\begin{array}{l}5 \cdot 5 \\
4 \cdot 0\end{array}$ & $\begin{array}{l}38 \cdot 0 \\
65 \cdot 5\end{array}$ & $\begin{array}{l}7.6 \\
8.8\end{array}$ & $\begin{array}{l}24 \cdot 8 \\
11 \cdot 1\end{array}$ & $\begin{array}{r}13 \cdot 1 \\
9 \cdot 1\end{array}$ & $\begin{array}{r}16 \cdot 5 \\
5 \cdot 5\end{array}$ & 330 & 139 & 58 \\
\hline $\begin{array}{l}6 \cdot 8 \\
2 \cdot 4\end{array}$ & $\begin{array}{r}66 \cdot 7 \\
4 \cdot 2\end{array}$ & $\begin{array}{l}7 \cdot 7 \\
2 \cdot 2\end{array}$ & 9.4 & $\begin{array}{l}11 \cdot 4 \\
56 \cdot 3\end{array}$ & $\begin{array}{r}6 \cdot 0 \\
37 \cdot 3\end{array}$ & 195 & 48 & 75 \\
\hline
\end{tabular}

Composition of Sera on Fig. 3

\begin{tabular}{|c|c|}
\hline $\begin{array}{c}\text { B.F. (Toxaemia } \\
\text { of pregnancy) }\end{array}\left\{\begin{array}{l}\text { Serum } \\
\text { Uroprotein }\end{array}\right.$ & $\cdots$ \\
\hline $\begin{array}{l}\text { B.F. (Gen. } \\
\text { osteoporosis }, \text { Serum } \\
\text { Bence-Jones }\end{array}$ & $\begin{array}{l}\cdots \\
\cdots\end{array}$ \\
\hline
\end{tabular}


curve (see grey areas in Figs. 2 and 3). The point of departure on the paper strip is marked with $\leftarrow \bigcirc$ or $\uparrow$; if a paper strip is marked with $P$ it has been stained with bromphenol blue for proteins; and if it is marked with $\mathrm{L}$ it has been stained with "ciba" blue-Sudan black for lipoids. The diagrams in Figs. 2 and 3 are of sera selected for their marked alteration in lipoid composition. The diagrams of both cases of lipoid-nephrosis shown in Fig. 2 have a similar protein composition, and should be compared with Table II, where their lipoid composition is obviously different. The technique compares favourably with the time-consuming procedure for chemical lipoid analysis, although the latter methods are necessary when a quantitative estimate of the different lipoid components is required. Attempts at a differentiation of lipoid components by staining were not successful, although Nile-blue sulphate (Roulet, 1948) was also tried.

In Fig. 3 (uppermost) a case of toxaemia of pregnancy (ct. Table III) with a prominent lipoidcontent of $\alpha_{2}$ and $\beta$ globulins is shown. In spite of this finding we were not able to stain any lipoids in the uroprotein of the same patient (Fig. 3, right upper corner) even when $20 \mathrm{mg}$. of uroprotein was applied to the paper strip. The same was true for Bence-Jones protein from a patient with osteoporosis (Fig. 3). The lowest diagram is characteristic for a highly turbid serum with a high content of neutral fat. This component is not moved by the electrical field, but remains on the spot where the serum has been applied. Evidently it would be wrong to describe it as a lipoidcomponent of $\gamma$ globulin, which in this instance is almost free of lipoid. In fact this serum was so turbid that the cadmium reaction was not visible. It appears that other lipoid components, like phospholipids and fatty acids, migrate to the same places as $\alpha$ and $\beta$ globulins.

\section{Summary}

By staining isolated serum protein fractions on filter paper with bromphenol blue, amidoblack, and azocarmine it has been proved that the last dye stains them most effectively. A simple method is described for staining the lipoids on filter paper after electrophoresis. Examples are given where the combined stain with "ciba" blue and Sudan black reveals different lipoid composition.

\section{REFERENCES}

Caspani, R. (1952). Minerva med., Torino, 43 (1), 1346.

and Sticca, C. (1952). Ibid., 43 (2), 749

Cre ner D. and Tiselius, A. (1950). Piochem. Z., 320, 273.

Esser, H., Heinzler, F., Kazmeier, F., and Schotan, W. (1952) Artzl. Forsch., 6, 156

Flynn, F. V., and Mayo, P. de (1951). Lancet, 2, 235.

Glick, D. (1949). Techniques of Histo- and Cyto-chemistry, pp. $39-40$. Interscience, New York.

Grassmann, W.2 and Hannig, K. (1950). Naturwissenschaften, 37, 397,496

L (1952). Hopp?-Seyl. Z., 290, 1.

Köiw, E., Wallenius, G., and Grönwall, A. (1952). Scand. J. clin. L.ab. Invest., 4, 47.

Kunkel, H. G., and Slater, R. J. (1952). J. clin. Invest., 31, 677. - and Tiselius, A. (1951). J. gen. Physiol., 35, 89.

Plückthun, H., and Götting, H. (1951). Klin. Wschr., 29, 415.

Roulet, F. (1948). Methoden der pathologischen Histologie, p. 194 Springer, Vienna.

Swahn, B. (1952). Scand. J. clin. Lab. Invest., 4, 98.

Wallenius, G. (1952). Acta Soc. Med. upsalien, 57, 138.

Wunderly, C. (1952). Nature, Lond., 169, 932.

and Cagianut, B. (1952). Ann. Oculist., Paris, 185, 414.

and Pezold, F. A. (1952). Naturwissenschaften, 39, 493. 